\title{
STRATEGI COMMUNITY RELATIONS PT PERTAMINA HULU ENERGI WEST MADURA OFFSHORE DALAM MELAKSANAKAN PROGRAM CSR SI KOMO PASIR - TAMAN PENDIDIKAN MANGROVE (2013-2017)
}

\author{
Abraham Natanael Nainggolan ${ }^{1^{*}}$, Titi Nur Vidyarini ${ }^{2}$, Yustisia Ditya Sari ${ }^{3}$ \\ ${ }^{1,2,3}$ Prodi Ilmu Komunikasi, Universitas Kristen Petra Surabaya \\ Jl. Siwalankerto 121-131, Surabaya 60236, INDONESIA \\ *Penulis korespondensi; Email: abrahamnatanael.an@gmail.com
}

\begin{abstract}
ABSTRAK
PHE WMO menjalin hubungan baik dan memberikan kontribusi pada komunitas lokal dalam wujud Program CSR Si Komo Pasir - Taman Pendidikan Mangrove. Program ini merupakan program CSR pertama di Madura dan Indonesia yang berkonsep konservasi lingkungan berbasis komunitas. Program yang dimulai dari tahun 2013 ini telah meraih penghargaan tertinggi CSR, yaitu PROPER EMAS dari KLHK dan Wakil Presiden RI serta sesuai dengan SDGs. Akan tetapi, hingga tahun 2017 masih terdapat permasalahan komunitas yang belum selesai, yaitu Braind Drain (Usia Produktif Merantau) mencapai 208 KK dan 120 Rumah Tangga miskin yang berpengaruh terhadap reputasi perusahaan dan perkembangan Taman Pendidikan Mangrove kedepannya. Penelitian ini dilakukan untuk mengetahui strategi Community Relations PHE WMO dalam melaksanakan program CSR Si Komo Pasir - Taman Pendidikan Mangrove dari tahun 2013 hingga 2017. Penelitian ini menggunakan pendekatan kualitatif deskriptif dan menggunakan metode studi kasus. Strategi Community Relations yang ditemukan dalam penelitian ini, digolongkan dalam delapan strategi, yaitu mengidentifikasi masyarakat, melakukan engagement masyarakat, melakukan kerjasama dengan konsultan sesuai kebutuhan, memberikan pendidikan dan pelatihan kepada masyarakat, melibatkan masyarakat dalam perencanaan dan implementasi program CSR, melakukan pendampingan rutin dan pengelolaan isu masyarakat, memberikan program dukungan masyarakat, dan memberikan apresiasi atau penghargaan kepada masyarakat.
\end{abstract}

Kata kunci: Community Relations; Strategi Community Relations; Corporate Social Responsibility; Program CSR Si Komo Pasir-Taman Pendidikan Mangrove

\begin{abstract}
PHE WMO was maintained good relationship and contributes to the local community in the form of CSR Program Si Komo Pasir - Mangrove Education Park. This program is the first CSR program in Madura and Indonesia with the concept of community-based environmental conservation. The program, which began in 2013, has won the highest award of CSR, the GOLD PROPER from Environment \& Forestry Minister and Vice President of Indonesia and in accordance with the SDGs. However, until 2017 there are still unfinished community problems, namely Braind Drain, reaching 208 families and 120 poor households that affect the company's reputation and the development of Mangrove Education Park going forward. This research is conducted to know the strategy of Community Relations of PHE WMO in implementing CSR program Si Komo Pasir - Mangrove Education Park from 2013 to 2017. This research used descriptive qualitative approach and using case study method. The Community Relations strategy found in this research is classified into eight strategies: identifying the community, engagement of the community, cooperating with the consultant as needed, providing education and training to the community, involving the community in planning and implementing the CSR program, providing routine assistance and management Community issues, providing community support programs, and giving appreciation to the community.
\end{abstract}

Keywords: Community Relations, Community Relations Strategy, Corporate Social Responsibility, CSR Program "Si Komo Pasir-Taman Pendidikan Mangrove"

\section{PENDAHULUAN}

Akhir Tahun 2016, PT. Pertamina Hulu Energi (PHE) konsisten mempertahankan eksistensinya sebagai salah satu dari lima perusahaan minyak dan gas bumi dengan jumlah lifting (produksi migas yang siap jual) tertinggi di Indonesia, yaitu 36,500 BOPD (CNN Indonesia, 2017). Prestasi tersebut tentu tidak lepas dari kiprah salah satu anak perusahaan PHE yang turut menyumbangkan lifting tersebut, yaitu PT. Pertamina Hulu Energi West Madura Offshore (PHE WMO). Hingga akhir tahun 2016, PHE WMO mampu menyumbangkan lifting minyak sebesar 13,453 BOPD dan produksi gas sebesar 103,77 MMSCFD. Pencapaian tersebut melebihi target WP\&B 2016 dari SKK Migas sebesar 111,9\% produksi minyak dan $103 \%$ produksi gas (Metrotvnews.com, 2016). Pencapaian tersebut juga 
dapat memenuhi kebutuhan minyak dan gas bumi di Provinsi Jawa Timur dan mampu memberikan kontribusi sebesar 1,2 triliun rupiah untuk pembangunan infrastruktur bagi kesejahteraan masyarakat sekitar daerah operasi. (Laporan Keberlanjutan PHE WMO, 2016)

PHE WMO selain berkontribusi besar pada kebutuhan minyak dan gas negara, PHE WMO juga memiliki komitmen yang tinggi untuk melestarikan lingkungan dan menyejahterakan kehidupan masyarakat sekitar daerah operasi/lapangan minyak. Pada tanggal 7 Desember 2016, PHE WMO meraih penghargaan tertinggi peduli lingkungan, yaitu PROPER EMAS yang diberikan oleh Menteri Lingkungan Hidup dan Kehutanan beserta Wakil Presiden Indonesia (Jawa Pos.com, 2016). Penghargaan ini membawa PHE WMO menjadi perusahaan offshore minyak dan gas pertama di Indonesia yang meraih penghargaan tersebut (AntaraNews.com, 2016). Penghargaan ini juga merupakan penghargaan terbaik selama 4 tahun sebelumnya secara berturut-turut PHE WMO meraih PROPER HIJAU.

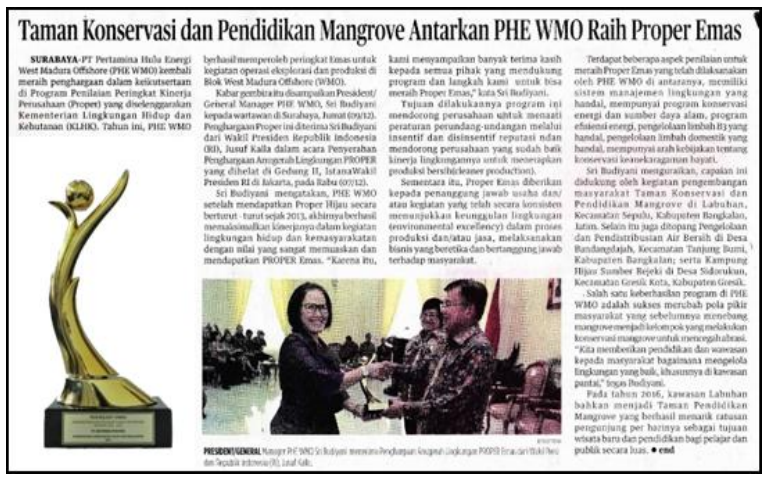

Gambar 1. Berita Penghargaan PROPER EMAS 2016 (Jawa Pos)

Komitmen PHE WMO untuk melestarikan lingkungan dan menyejahterakan masyarakat dinyatakan dalam program-program CSR yang dilakukannya. Terdapat 3 program CSR PHE WMO yang bertajuk pemberdayaan masyarakat dan lingkungan, yaitu $\mathrm{Si}$ Komo Pasir (Aksi Konservasi Mangrove Berbasis Pemberdayaan Masyarakat Pesisir)-Taman Pendidikan Mangrove, Sidorukun Kampung Hijau Sumber Rejeki, dan Air Bersih Berkelanjutan HIPPAM Sumber Barokah. Berdasarkan wawancara dengan Hardian, Community Development Officer PHE WMO, pada tanggal 1 April 2017, program CSR Si Komo Pasir-Taman Pendidikan Mangrove merupakan program unggulan PHE WMO dan berbeda dari program CSR yang lain karena berhasil merubah pola perilaku dan karakter masyarakat pesisir Desa
Labuhan, Madura yang unik dan kontras dengan kehidupan mereka saat ini.

Program CSR Si Komo Pasir - Taman Pendidikan Mangrove merupakan inovasi berkelanjutan dengan konsep konservasi lingkungan berbasis komunitas (conservation based community) yang mendasarkan pada kemandirian masyarakat untuk menuju kehidupan yang lebih baik. PHE WMO melalui program tersebut berusaha menciptakan suasana hubungan yang baik (bermitra) dengan komunitas masyarakat hampir selama 3 tahun melalui usahausaha sistematisnya untuk menciptakan mutu kehidupan masyarakat. Hal ini dibuktikan oleh ungkapan hati masyarakat Desa Labuhan yang merupakan salah satu anggota masyarakat sekitar daerah operasi perusahaan PHE WMO.

"Lebbi Bagus Abangun Dhisah Dhibik e Tembeng Neng Rantau Oreng. Saya merasa terharu dan sangat terbuka wawasan saya saat melihat di Taman Pendidikan Mangrove banyak potensi yang bisa dikembangkan dan begitu banyaknya turis yang hadir disana. Yang dulunya saya selalu hidup dengan tidak punya harapan yang baik maka saya pergi merantau ke Malaysia akan tetapi saya kembali pulang karena tidak ada kedamaian. Dan setelah saya kembali dan melihat Taman Pendidikan Mangrove yang dibangun oleh PHE WMO bersama masyarakat saya menjadi yakin dan penuh harapan bahwa lebih baik membangun desa sendiri daripada merantau ke negeri orang. Saya juga mendapatkan pelatihan dan pembinaan dari PHE WMO, saya mendapatkan banyak pengetahuan tentang bagaimana menjaga mangrove. Mangrove ternyata memberikan banyak manfaat, khususnya bagi desa kami yang sering terkena abrasi pantai. Selain itu, hidup kami berbeda dengan yang dulu, sekarang kami menjadi semakin sejahtera. (Wawancara 20 Januari 2017 dengan Sahril, 40 Tahun, Profesi sebagai PIC Silvopasturi Taman Pendidikan Mangrove dan menjadi Local Hero pilihan Pertamina tahun 2016)"

Pada tahun 2013, PHE WMO menemukan bahwa abrasi pantai tersebut disebabkan oleh adanya pembalakan liar hutan mangrove yang cukup tinggi sehingga terjadi kerusakan dan kawasan pesisir menjadi gersang. Hal ini turut menyebabkan desa Labuhan menjadi desa dengan tingkat kekritisan mangrove paling tinggi dibandingkan dengan 5 desa lainnya. Disamping itu, adanya jenis mangrove langka yaitu Sentigi (Pemphis Acidula) yang tumbuh di desa Labuhan ini juga menjadi alasan sering 
terjadinya pembalakan liar. Tanaman Sentigi ini dijadikan sebagai bonsai dan dijual sehingga menjadi salah satu komoditas ekonomi masyarakat sekitar, yang mayoritas dikategorikan miskin. Sedangkan tanaman Sentigi yang sudah tua (lebih dari 50 tahun) dipercayai masyarakat setempat memiliki kekuatan supranatural dan banyak dari mereka menjadikannya kalung maupun tongkat. Dalam hal ini, dapat dikatakan bahwa kerusakan lingkungan bukan disebabkan oleh adanya anjungan migas PHE WMO akan tetapi disebabkan oleh ulah masyarakat sendiri.

Pada tanggal 5 Juni 2013, Pimpinan Direksi dan Staff PHE WMO bersama masyarakat setempat, Institusi Pendidikan, Lembaga Swadaya Masyarakat dan Instansi Pemerintahan melakukan penanaman 10.000 bibit mangrove di pesisir pantai desa Labuhan. Aksi tersebut selain untuk memperingati Hari Lingkungan Hidup Sedunia sekaligus sebagai langkah awal PHE WMO dalam mengembangkan CSR Si Komo PasirTaman Pendidikan Mangrove. (Energitoday.com, 2013).

Pada tahun 2016, kawasan pesisir desa Labuhan yang dulunya gersang telah bertransformasi menjadi sentra Taman Pendidikan Mangrove. Berdasarkan wawancara dengan President/General Manager PHE WMO, Sri Budiyani, pada tanggal 28 Oktober 2016, Taman Pendidikan Mangrove Labuhan telah menjadi kawasan wisata edukasi mangrove pertama di Madura dan di Indonesia (Sumber: Wawancara dengan Mangrove Center Tuban) dimana telah dilengkapi dengan sarana prasarana penunjang untuk kegiatan wisata, education tour dan penelitian, mencakup mangrove trekking, bird watching, saung mangrove, jelajah perahu, pulau ajaib, kolam adopsi \& kolam sentuh, mangrove green camping, perpustakaan, aula tempat pertemuan, MCK, mushola, dan didukung pengembangan silvopasturi (integrasi pengelolaan mangrove dengan potensi perikanan dan perkebunan), seperti tambak kepiting soka dan budidaya papaya calina. Dan semua pengelolaan Taman Pendidikan Mangrove dikelola oleh masyarakat Desa Labuhan. Sejak peresmian dan pembukaan Taman Pendidikan Mangrove pada bulan September 2016 jumlah pengunjung telah mencapai angka 4.844 orang dan pengunjung yang datang selain penduduk asli Madura juga berasal dari Jawa Timur, Jawa Tengah, Jawa Barat, DKI Jakarta dan Luar Negeri (Czech Republic). Selain itu, pengunjung juga berasal dari berbagai institusi, seperti, media, lembaga penelitian dan pendidikan, komunitas studi, SD-SMA, dan Universitas.
Pada tahun 2017, di saat sebuah Taman Pendidikan Mangrove telah lahir dan didirikan, timbul sebuah dinamika permasalahan yang lain, yaitu Brain Drain (Usia Produktif Merantau) yang mencapai 208 KK warga desa merantau dan masih terdapat 120 Rumah Tangga miskin. Masyarakat yang tinggal di Desa Labuhan dengan usia produktif memilih untuk merantau ke luar negeri ataupun luar pulau dari pada mengembangkan desanya, padahal dalam mengembangkan Taman Pendidikan Mangrove dibutuhkan tenaga-tenaga dengan usia produktif. Selain itu, juga adanya konflik masyarakat mengenai pembagian hasil keuntungan dari aktivitas Taman Pendidikan Mangrove sehingga pembagian hasil tidak merata yang menyebabkan masih ada masyarakat yang miskin dan hidup tidak layak. Hal ini seperti yang disampaikan oleh Ulika Putrawardana, Head of HR Operations \& Community Development - East Java (Field Operations Manager) PHE WMO, dalam wawancara 10 Maret 2017.

Dalam pelaksanaan CSR Taman Pendidikan Mangrove dari tahun 2013 hingga 2017 sekarang ini, ada beberapa aktivitas Public Relations yang dilakukan seperti, Media Relations, Government Relations, dan Community Relations. Dalam penelitian ini, peneliti fokus melihat Community Relations, mengingat Community Relations berhadapan langsung dengan persoalan-persoalan sosial yang nyata yang dihadapi komunitas sekitar organisasi. Melalui pendekatan Community Relations, perusahaan bersama-sama dengan komunitas sekitarnya berusaha untuk mengidentifikasi, mencari solusi, dan melaksanakan rencana tindak atas permasalahan yang dihadapi atau menentukan strategi yang tepat dalam menyelesaikan masalah tersebut. Dalam hal ini, fokusnya adalah permasalahan yang dihadapi komunitas. (Iriantara, 2013, p.34).

Baskin, Aronoff, dan Lattimore mengatakan Community Relations adalah suatu perencanaan lembaga, aktif, partisipasi yang terus menerus dengan dan dalam sebuah komunitas untuk memelihara dan meningkatkan lingkungan agar keduanya, baik lembaga maupun komunitas memperoleh manfaat (Ardianto \& Machfuds, 2011, p.33). Maka dari itu, dalam setiap melaksanakan kegiatan Community Relations diperlukan strategi yang sesuai dalam merencanakannya. Sesuai yang dikemukakan oleh Edmund Burke dalam bukunya Corporate Community Relations (2001; 101), menjalin hubungan dengan komunitas dibutuhkan strategi-strategi yang tepat, yaitu building relationship of trust, managing community issues and concerns, dan using community 
support program to build trust. Dalam penelitian ini, peneliti hendak melihat seperti apa Community Development \& Relations (Public Relations) PHE WMO dalam menentukan strategi Community Relations dalam melaksanakan program CSR Si Komo Pasir Taman Pendidikan Mangrove.

Penelitian ini juga menjadi menarik dimana PHE WMO sebagai perusahaan offshore migas satusatunya yang telah mendapatkan sebuah penghargaan tertinggi lingkungan dan pemberdayaan masyarakat, yaitu PROPER EMAS masih ada permasalahanpermasalahan komunitas yang muncul yang juga dapat menurunkan reputasi PHE WMO. Dimana, hal ini juga kontras dengan tujuan PHE WMO dalam melaksanakan Program CSR Taman Pendidikan Mangrove, yaitu untuk melindungi area Ring 1 Operasi serta melakukan pemberdayaan masyarakat secara merata sehingga memunculkan kemandirian hingga tahun 2018 dan telah merencanakan sebuah pengembangan berkelanjutan hingga 2023. Oleh karena itu, penting untuk melihat bagaimana strategi Community Relations PHE WMO di awal dan masa kini dalam melaksanakan Program CSR Si Komo Pasir-Taman Pendidikan Mangrove untuk menjawab permasalahan tersebut.

Berdasarkan fenomena yang telah diuraikan di atas, peneliti tertarik untuk meneliti Strategi Community Relations yang dilakukan oleh PT. Pertamina Hulu Energi WMO dalam melaksanakan Program CSR Si Komo Pasir-Taman Pendidikan Mangrove. Penelitian ini diharapkan dapat membantu PT. Pertamina Hulu Energi WMO untuk melihat kembali kegiatan Community Relations dengan wujud Program CSR Si Komo Pasir-Taman Pendidikan Mangrove yang telah dilaksanakan terhadap citra korporat yang positif di mata publiknya. Dan juga dapat menjadi referensi perusahaan migas lainnya dalam melaksanakan kegiatan Community Relations. Metode yang dipakai adalah metode studi kasus dengan pendekatan kualitatif deskriptif.

\section{TINJAUAN PUSTAKA}

\subsection{Teori Kontrak Sosial}

Kontrak sosial dibangun dan dikembangkan, salah satunya untuk menjelaskan hubungan antara perusahaan dan masyarakat. Di sini, perusahaan atau organisasi memiliki kewajiban pada masyarakat untuk memberi manfaat bagi masyarakat. Interaksi perusahaan dengan masyarakat akan selalu berusaha untuk memenuhi dan mematuhi aturan dan normanorma yang berlaku di masyarakat, sehingga kegiatan perusahaan dapat dipandang legitimate. (Deegan, dalam Ardianto \& Machfudz, 2011, p.77).

\subsection{Community Relations}

Community Relations atau hubungan komunitas merupakan sebuah fungsi Public Relations. Menurut Baskin, Aronoff, dan Lattimore, Community Relations adalah suatu perencanaan lembaga, aktif, dan partisipasi yang terus menerus dengan dan dalam sebuah komunitas untuk memelihara dan meningkatkan lingkungan agar keduanya, baik lembaga maupun komunitas memperoleh manfaat. (Ardianto \& Machfudz, 2011, p.66). Salah satu usaha yang dapat dilakukan oleh perusahaan dalam menjalin hubungan kemitraan yang baik dengan komunitas adalah program Community Relations. Menurut Jerold, Communitty Relations sebagai peningkatan partisipasi dan posisi organisasi didalam sebuah komunitas melalui berbagai upaya kemaslahatan bersama bagi organisasi dan komunitas (Iriantara, 2013, p.7).

\subsection{Strategi Community Relations}

Community Relations pada dasarnya dikembangkan untuk kemaslahatan bersama organisasi dan komunitas. Berdasarkan hal tersebut, menurut Edmund M. Burke dalam bukunya berjudul "Corporate Community Relations" (2001, p.101-157), menjalin hubungan dengan komunitas membutuhkan strategistrategi yang tepat dalam melaksanakannya, yaitu:

1. Building Sustainable Relationships Of Trust

Dalam Burke (2001, p.102), sebuah tujuan dari Community Relations adalah membangun hubungan warisan kepercayaan (legacy of trust) antara perusahaan dengan komunitasnya. Cara utama untuk membangun kepercayaan adalah melalui hubungan berkelanjutan dengan individu kunci dan organisasi di dalam sebuah komunitas. Hubungan kepercayaan, bagaimanapun, tidak diraih dengan mudah, santai, atau cepat. Sebuah komunitas tidak dikembangkan dengan hanya mengenal orang atau menghadiri fungsi masyarakat. Mereka bergantung pada catatan integritas perusahaan di komunitas.

2. Managing Community Issues and Concerns

David Grier, dikenal sebagai Community Relations Specialist dari Royal Bank Canada. David (dalam Burke, 2001, p.114) mendeskripsikan bahwa isu adalah sebuah gap antara Corporate Action dan Stakeholder Expectations. Cara di mana sebuah perusahaan merespon persepsi mempengaruhi tingkat kepercayaan di masyarakat. Akibatnya, untuk membangun kepercayaan 
perusahaan perlu banyak belajar bagaimana cara untuk mengantisipasi dan menanggapi kekhawatiran masyarakat dan isu-isu yang terjadi. Edmund M. Burke dalam bukunya menjelaskan mengenai cara melihat characteristics of social issues dalam sebuah komunitas, yaitu: meaning of issues, community origin of issues, life cycle of issues.

3. Using Community Support Programs To Build Trust

Dalam Burke (2001, p.125), strategi ketiga untuk menjadi a neighbour of choice adalah melalui penggunaan perencanaan program dukungan komunitas. Ini tidak mudah untuk membenarkan filantropi perusahaan. Perusahaan telah dikritik karena memberikan pendapatan pemegang saham untuk amal. Tapi semua itu di masa lalu. Masyarakat saat ini berharap perusahaan untuk terlibat dalam memecahkan masalah masyarakat dan memberikan kontribusi uang untuk meningkatkan pelayanan masyarakat. "A Global Econo$m y$," kata Rosabeth Moss Kanter dalam bukunya berjudul World Class, memaksa konsepsi yang lebih luas dari masyarakat dan kepemimpinan bisnis. Ini tidak boleh disamakan hanya dengan uang, tetapi dengan keterlibatan dalam kegiatan yang berkontribusi terhadap kualitas hidup komunitas.

\subsection{Corporate Social Responsibility: Triple Bottom Lines}

Triple Bottom Line dipopulerkan oleh John Elkington pada tahun 1997 melalui bukunya "Cannibals with Forks, the Triple Bottom Line of Twentieth Century Business". Elkington mengembangkan konsep Triple Bottom Line dalam istilah economic prosperity, enviromental quality, dan social justice. Melalui buku tersebut, Elkington memberi pandangan bahwa perusahaan yang ingin berkelanjutan, haruslah memperhatikan "3P". Selain mengejar profit, perusahaan juga mesti memperhatikan dan terlibat pada pemenuhan kesejahteraan masyarakat (people) dan turut berkontribusi aktif dalam menjaga kelestarian lingkungan (planet). (Wibisono, 2007, p. 32)

\section{METODE}

\subsection{Konseptualisasi Penelitian}

Dalam penelitian ini metode yang digunakan peneliti adalah metode studi kasus. Studi kasus merupakan strategi yang lebih cocok karena pokok pertanyaan suatu penelitian berkenaan dengan how atau why, bila peneliti memiliki sedikit peluang untuk mengontrol peristiwa-peristiwa yang akan diselidiki. Sebagai suatu upaya penelitian, studi kasus dapat memberi nilai tambah pada pengetahuan peneliti secara unik tentang fenomena individual, organisasi, sosial dan politik. Pada semua situasi, kebutuhan akan studi kasus melampaui keinginan untuk memahami fenomena sosial yang kompleks. Singkatnya, studi kasus memungkinkan peneliti untuk mempertahankan karakteristik holistik dan bermakna dari peristiwa peristiwa kehidupan nyata seperti siklus kehidupan seseorang, proses-proses organisasional dan manajerial, perubahan lingkungan sosial, hubunganhubungan internasional, dan kematangan industri industri. (Yin, 2009, p.1). Tujuan studi kasus adalah meningkatkan pengetahuan mengenai peristiwaperistiwa komunikasi kontemporer yang nyata dalam konteksnya. Metode riset ini menggunakan berbagai sumber data yang dapat dipakai untuk menguraikan bidang yang diteliti dengan lebih sistematis. Dalam hal ini, kasus yang diteliti adalah fenomena strategi Community Relations PT. Pertamina Hulu Energi West Madura Offshore dalam melaksanakan program CSR Si Komo Pasir - Taman Pendidikan Mangrove.

\subsubsection{Subjek Penelitian}

Subjek penelitian ini, yaitu Departemen Community Development \& Relations PHE WMO yang menjalankan Program CSR Si Komo Pasir - Taman Pendidikan Mangrove. Peneliti ingin melihat strategi Community Relations di PT. Pertamina Hulu Energi West Madura Offshore, khususnya dalam melaksanakan program CSR Si Komo Pasir-Taman Pendidikan Mangrove. Objek penelitian ini adalah strategi Community Relations yang dilakukan Community Development PT. Pertamina Hulu Energi West Madura Offshore.

\subsubsection{Analisis Data}

Dalam penelitian ini, peneliti menggunakan teknik analisis interaktif Miles dan Huberman Teknik analisis ini terdiri dari tiga komponen, yaitu reduksi data, penyajian data, penarikan serta pengujian kesimpulan (Pawito, 2007, p.106). Reduksi data dalam hal ini bukan asal membuang data yang tidak diperlukan melainkan merupakan upaya yang dilakukan oleh peneliti selama analisis data dilakukan dan merupakan langkah yang tak terpisahkan dari analisis data.

\subsection{Temuan Data}

Berikut adalah hasil temuan data mengenai Strategi Community Relations PHE WMO dalam melaksanakan Program CSR Si Komo Pasir-Taman 
Pendidikan Mangrove. Hasil temuan ini terbagi dalam delapan bagian besar strategi Community Relations.

\subsubsection{Identifikasi Masyarakat}

Strategi pertama adalah mengidentifikasi masyarakat yang dilakukan sebelum masuk ke dalam masyarakat. Hal tersebut dilakukan dengan pemetaan sosial (social mapping), memotret kondisi fisik lingkungan Desa Labuhan, menggolongkan kelompok-kelompok yang ada di masyarakat, mengamati interaksi antar tokoh di masyarakat, dan melihat apa pengaruh yang dihasilkan dari interaksi antar tokoh tersebut. Dalam proses ini, peneliti melihat PHE WMO dibantu oleh pihak ketiga, yaitu lembaga pendidikan Universitas Trunojoyo Madura. Adanya lembaga pendidikan membantu PHE WMO mengumpulkan fakta mengenai kondisi sosial masyarakat.

\subsubsection{Engagement Masyarakat}

Strategi kedua adalah melakukan engagement kepada masyarakat. Setelah PHE WMO mengetahui sebuah gambaran mengenai masyarakat Desa Labuhan, strategi selanjutnya adalah masuk ke dalam masyarakat dan menjalin komunikasi dengan masyarakat. Pada tahap identifikasi masyarakat, dipaparkan sebuah jaringan atau pola interaksi antar tokoh penting di desa Labuhan. PHE WMO masuk melalui tokohtokoh tersebut dan menjalin komunikasi mengenai tujuan kedatangan PHE WMO. Comdev PHE WMO menjalin komunikasi dengan Kepala Desa, tokohtokoh masyarakat, tokoh-tokoh ulama, guru ngaji, dan sebagainya. Selanjutnya, PHE WMO mulai merasakan nature masyarakat Labuhan dan bagaimana respon masyarakat terhadap permasalahan kritis yang terjadi lingkungan mereka, antusias atau tidak. PHE WMO saat masuk kemasyarakat juga melakukan live in selama tiga hari. Live in dalam arti Comdev PHE WMO bermalam di rumah masyarakat dan mengikuti kegiatan sehari-hari masyarakat. Selama live in, Comdev PHE WMO melakukan diskusi dengan masyarakat diselingi dengan canda tawa. PHE WMO saat masuk kedalam masyarakat menggunakan strategi, yaitu mengosongkan pikiran, stigma, dan stereotype mengenai masyarakat Labuhan yang merupakan suku Madura. Selain itu, Comdev PHE WMO harus memiliki paramater saat masuk ke dalam masyarakat. Dalam arti mereka harus mengerti apa yang boleh dilakukan dan apa yang tidak boleh dilakukan saat berinteraksi dengan masyarakat ( $d o$ and dont's). Dalam melakukan diskusi atau musyawarah PHE WMO melihat beberapa dari masyarakat merasa tertarik untuk segera mengatasi permasalahan tersebut dan beberapa dari mereka masih merasa apatis tetapi mau terlibat. Saat itu juga tantangannya adalah dinamika sosial dan karakter sosial orang Madura dimana mereka tidak mau bekerja jika tidak ada uangnya. Selain itu, orang Madura jika diajak berbicara topiknya adalah bukan urusan praktis dan pragmatis. Mereka berpikir bahwa tidak ada gunanya menanam dan menyelamatkan lingkunngan. PHE WMO menanggapi hal tersebut sebagai dinamika sosial dan bagian dari masalah yang harus segera diselesaikan. PHE WMO menanganinya dengan sikap tegas dan tidak mengangap itu sebagai barrier atau penghambat dalam pelaksanaan program Taman Pendidikan Mangrove ini.

\subsubsection{Kerjasama dengan Konsultan Sesuai Ke- butuhan}

PHE WMO setelah melakukan engagement dengan masyarakat, kemudian menyepakati bahwa untuk mengatasi permasalahan lingkungan tersebut harus melakukan pembibitan bukan penanaman. Comdev PHE WMO melihat ada beberapa tanaman di Labuhan yang berpotensi untuk tumbuh kembang sehingga akan lebih mudah dari pada membawa bibit dari luar lalu ditanam di pesisir Labuhan. Potensi tanaman itu adalah tanaman mangrove jenis sentigi. Selanjutnya, PHE WMO berencana memulai melakukan pembibitan mangrove akan tetapi tidak tahu bagaimana melakukannya. Strategi selanjutnya yang diambil oleh PHE WMO adalah menghubungi beberapa konsultan mangrove yang ada. Comdev PHE WMO mempertimbangkan aspek-aspek pemilihan terhadap konsultan yang akan dijadikan mitra tersebut dan akhirnya PHE WMO memilih Mangrove Centre Tuban (MCT). PHE WMO yang memiliki kondisi untuk bermitra dengan Mangrove Centre Tuban (MCT), membuat PHE WMO harus pergi ke sana untuk membuka komunikasi awal dan melakukan engagement dengan lembaga tersebut.

\subsubsection{Pendidikan dan Pelatihan Masyarakat}

Strategi keempat adalah memberikan pendidikan dan pelatihan kepada masyarakat. Dalam melaksanakan sebuah program CSR Si Komo Pasir-Taman Pendidikan Mangrove, salah satu bentuk strategi Community Relations PHE WMO adalah dengan memberikan pelatihan-pelatihan kepada masyarakat Labuhan. Pelatihan-pelatihan yang diberikan PHE WMO kepada masyarakat yang dilakukan terkait dengan pelaksanaan program CSR Si Komo Pasir Taman Pendidikan Mangrove adalah Pelatihan Pembibitan dan Penyemaian Tanaman Mangrove di Mangrove Centre Tuban serta Penguatan Kelembaga- 
an Kelompok Nelayan serta Pelatihan Pemandu Mangrove dan Manajemen Kepariwisataan di BPHM (Balai Pengelolaan Hutan Mangrove) Bali. Soekijo (2000, p.4) mengatakan bahwa untuk meningkatkan kualitas kemampuan yang menyangkut kemampuan spesifik, berpikir, dan keterampilan maka pendidikan dan pelatihan yang paling penting diperlukan.

\subsubsection{Melibatkan Masyarakat dalam Perencanaan \& Implementasi Program}

Strategi kelima adalah melibatkan masyarakat dalam perencanaan dan implementasi program CSR. PHE WMO dalam melaksanakan program CSR Si Komo Pasir-Taman Pendidikan Mangrove melibatkan masyarakat dalam proses perencanaan dan implementasinya. Dalam perencanaan program CSR ini PHE WMO bersama masyarakat melakukan focus group discussion. Comdev bersama MCT melibatkan masyarakat untuk menyusun perencanaan program dan action plan, mulai dari 5 tahun pertama dan kedua, rencana tahunan, dan membuat kelompok. Kelompok tersebut saat ini dinamakan Kelompok Tani Mangrove Cemara Sejahtera. Kelompok tersebut yang kemudian akan melakukan pembibitan mangrove dan mengembangkan kawasan konservasi Mangrove di labuhan. Setelah berhasil masuk kemasyarakat dan menyusun sebuah perencanaan, tibalah mengimplementasikan apa yang telah direncanakan. Sesuai dengan hasil diskusi dengan masyarakat bahwa akan di bangun sebuah kawasan konservasi mangrove yang dinamakan dengan Taman Pendidikan Mangrove, maka berjalanlah implementasi tersebut sesuai dengan roadmap yang ada. Roadmap berisi serangkaian program utama dalam melaksanakan program CSR. PHE WMO dalam mengimplementasikan serangkaian program yang tersusun di roadmap juga melibatkan elemen masyarakat. Salah satu contohnya, pada tahun 2013 dalam membangun saung mangrove PHE WMO melibatkan kepala desa dan kelompok Tani Mangrove Cemara Sejahtera secara penuh untuk membangun saung tersebut, mulai dari desain bangunan dan pembelian material bangunan.

\subsubsection{Pendampingan dan Pengelolaan Isu Masya- rakat}

Strategi keenam adalah memberikan pendampingan rutin dan pengelolaan isu masyarakat. Roadmap program CSR Si Komo Pasir-Taman Pendidikan Mangrove yang telah dibuat tentunya akan diimplementasikan. Dalam mengimplementasikan roadmap tersebut setiap dua minggu sekali Comdev PHE WMO melakukan pendampingan atau monitoring rutin di masyarakat. PHE WMO melihat bagaimana pelibatan masyarakat dalam pengembangan program tersebut. Comdev PHE WMO melakukan survey dan focus group discussion kepada masyarakat apakah pelatihan ini bermanfaat, apakah program pembangunan lancar, dan apakah mendapat nilai tambah bagi masyarakat. Nilai tambah yang dimaksudkan bisa income dan pengetahuan akan hal baru. Masyarakat dalam mengembangkan program CSR Si Komo Pasir - Taman Pendidikan Mangrove juga tidak luput dari beragam permasalahan yang terjadi. Permasalahan yang masih terjadi sampai saat ini adalah brain drain. Isu tersebut telah ada sejak pertama kali didirikannya Taman Pendidikan Mangrove. Brain dain dalam arti banyaknya masyarakat Labuhan yang pergi merantau ke luar kota ataupun luar negeri untuk bekerja dari pada membangun desanya. Dikaitkan dengan PHE WMO sebagai penyelenggara CSR dimana membutuhkan bantuan masyarakat untuk membangun desanya melalui program CSR Si Komo Pasir-Taman Pendidikan Mangrove. Apalagi program CSR ini telah mempunyai manajemen strategis dimana akan terus dikembangkan hingga 5 atau 10 tahun kedepan dan tentunya akan membutuhkan kader-kader masyarakat yang lebih banyak. PHE WMO dalam hal ini melakukan diskusi intens dengan masyarakat untuk menemukan bagaimana cara mengatasi hal tersebut. PHE WMO menjadikan masyarakat mitra untuk menyelesaikan masalah yang dialami masyarakat tersebut. Dalam melaksanakan pendampingan dan pengelolaan isu, PHE WMO tidak hanya mendapatkan informasi mengenai isu-isu di masyarakat melalui lisan (laporan masyarakat), tetapi bisa menemukan permasalahan itu dengan sendirinya menggunakan simbol-simbol, seperti insting dan kepekaan.

\subsubsection{Program Dukungan Masyarakat}

Strategi ketujuh adalah memberikan program dukungan masyarakat. Strategi Communitty Relations PHE WMO dalam melaksanakan Program CSR Si Komo Pasir-Taman Pendidikan Mangrove, yaitu melakukan program-program support kepada masyarakat secara spesifik. Dalam hal ini PHE WMO memberikan program-program dukungan masyarakat seperti memberikan edukasi mengenai jenis-jenis burung yang transit ke Labuhan kepada komunitas anak-anak di Labuhan, melibatkan ibu-ibu dalam program catering dimana hasil olahan catering mereka dipakai untuk menjamu wisatawan, mengajak pemuda-pemuda untuk mengikuti gerak jalan dalam rangka memperingati hari kemerdekaan dan merekrut mereka sebagai pegawai tetap (penjaga parkir) di Taman Pendidikan Mangrove, melakukan kegiatan 
gotong royong membersihkan pantai dan lingkungans sekitar kawasan konservasi mangrove, sponsorship kegiatan-kegiatan lokal masyarakat Labuhan, dan buka puasa bersama.

\subsubsection{Apresiasi atau Penghargaan Kepada Masya- rakat}

Strategi kedelapan adalah memberikan apresiasi atu penghargaan kepada masyarakat. PHE WMO setiap tahun memberikan penhargaan kepada masyarakat yang memiliki hasil karya luar biasa, dengan gagasan pokok yang mencerminkan jiwa kepemimpinan serta komitmen tinggi bagi lingkungan dan masyarakat di sekitar mereka. Salah satu bentuk apresiasinya adalah memilih Local Hero, karena tanpa local hero program tidak dapat berjalan dengan baik. PHE WMO mengundang masyarakat yang menjadi local hero ke Jakarta untuk sharing mengenai apa yang telah dilakukan dalam menjalankan suatu program CSR.

\section{ANALISIS DAN INTERPRETASI}

Community Development Pertamina Hulu Energi West Madura Offshore menginisiasi sebuah program Corporate Social Responsibility, yaitu Aksi Konservasi Mangrove Berbasis Pemberdayaan Masyarakat Pesisir (Si Komo Pasir) yang kemudian bertransformasi menjadi Taman Pendidikan Mangrove. Awalnya, Comdev PHE WMO melaksanakan program ini atas dasar untuk memenuhi rekomendasi RPL (Rencana Pemantauan Lingkungan Hidup) dari dokumen AMDAL (Analisis Mengenai Dampak Lingkungan) yang merupakan regulasi pemerintah. Program Taman Pendidikan Mangrove yang pada awalnya melakukan sebuah studi AMDAL ini sesuai dengan yang tertulis dalam Peraturan Pemerintah RI No. 27 tahun 1999 mengenai "Analisis Mengenai Dampak Lingkungan Hidup" (Peraturan.go.id, 2017). Dalam pasal 3 dan 4, dikemukakan bahwa setiap perusahaan yang memiliki jenis usaha atau kegiatan yang mengeksploitasi sumber daya alam baik yang terbaharui maupun yang tak terbaharui dan yang secara potensial dapat menimbulkan pemborosan, pencemaran dan kerusakan lingkungan hidup, serta kemerosotan sumber daya alam dalam pemanfaatannya wajib memiliki analisis mengenai dampak lingkungan hidup seperti yang ditetapkan oleh menteri. Dalam hal ini, PHE WMO merupakan perusahaan Badan Usaha Milik Negara yang melakukan ekploitasi dan eksplorasi sumber daya alam minyak dan gas di laut Madura. Oleh karena itu, tidak salah jika PHE WMO wajib melakukan AMDAL.
Sejak dari tahun 2011, PHE WMO telah menjadi anak perusahaan atau terakuisisi oleh BUMN Pertamina Hulu Energi dimana sebelumnya PHE WMO adalah perusahaan milik swasta dari Korea bernama Kodeco, Ltd. Maka dari itu, pada awal berdiri tahun 2011-2012, PHE WMO wajib melakukan studi AMDAL untuk memenuhi persyaratan dari peraturan pemerintah yang sudah dipaparkan sebelumnya. Dari hasil AMDAL tersebut disampaikan bahwa PHE WMO harus melakukan penguatan mangrove di sepanjang pesisir pantai utara Bangkalan dan ditemukan sebuah lokasi terdampak langsung operasi yaitu kecamatan Sepulu (Desa Labuhan). Desa Labuhan memiliki jarak hanya sekitar $3 \mathrm{~km}$ dari letak Anjungan migas PHE WMO di Laut Madura. Dari situlah, Comdev PHE WMO langsung melakukan penanaman mangrove dan penghijauan. Penanaman dilakukan bersama dengan pemerintahan setempat, yaitu Bupati Bangkalan dan Lembaga Pendidikan, yaitu Universitas Trunojoyo Madura. Akan tetapi, peneliti melihat PHE WMO tercetus melakukan penanaman mangrove dan penghijauan tersebut hanya sebatas ceremonial saja atau secara official diadakan sehingga hanya melakukan kegiatan yang sia-sia, yaitu hasil dari penanaman mangrove tersebut hanya 5\% yang tumbuh. PHE WMO kemudian melakukan evaluasi atas kegiatan penanaman mangrove dan penghijauan yang telah dilakukan bersama Pemerintahan setempat dan lembaga Universitas Trunojoyo Madura. Comdev PHE WMO melakukan diskusi dengan tim secara intens. PHE WMO kemudian menyadari bahwa ada salah satu hal yang tidak dilakukan sehingga menimbulkan kegagalan, yaitu tidak melibatkan unsur masyarakat dalam kegiatan tersebut. Permasalahan yang muncul adalah tidak melibatkan masyarakat dalam kegiatan CSR. Langkah PHE WMO selanjutnya dalam melaksanakan program CSR Si Komo Pasir - Taman Pendidikan Mangrove adalah mengubah strategi untuk memulai dari masyarakat atau mulai menjalin hubungan dengan masyarakat (Community Relations). Maka dari itu, dilakukan delapan strategi yang hasil analisis dan interpretasinya dapat dilihat dari bagan 1 .

\section{SIMPULAN}

PT. Pertamina Hulu Energi West Madura Offshore telah melakukan strategi Community Relations dengan komunitas sekitar daerah operasi perusahaannya, yaitu komunitas masyarakat Desa Labuhan dalam program CSR Si Komo Pasir-Taman Pendidikan Mangrove. Untuk mencapai keberhasilan program CSR tersebut, strategi Community Relations dikelompokkan dalam delapan strategi, yaitu meng- 


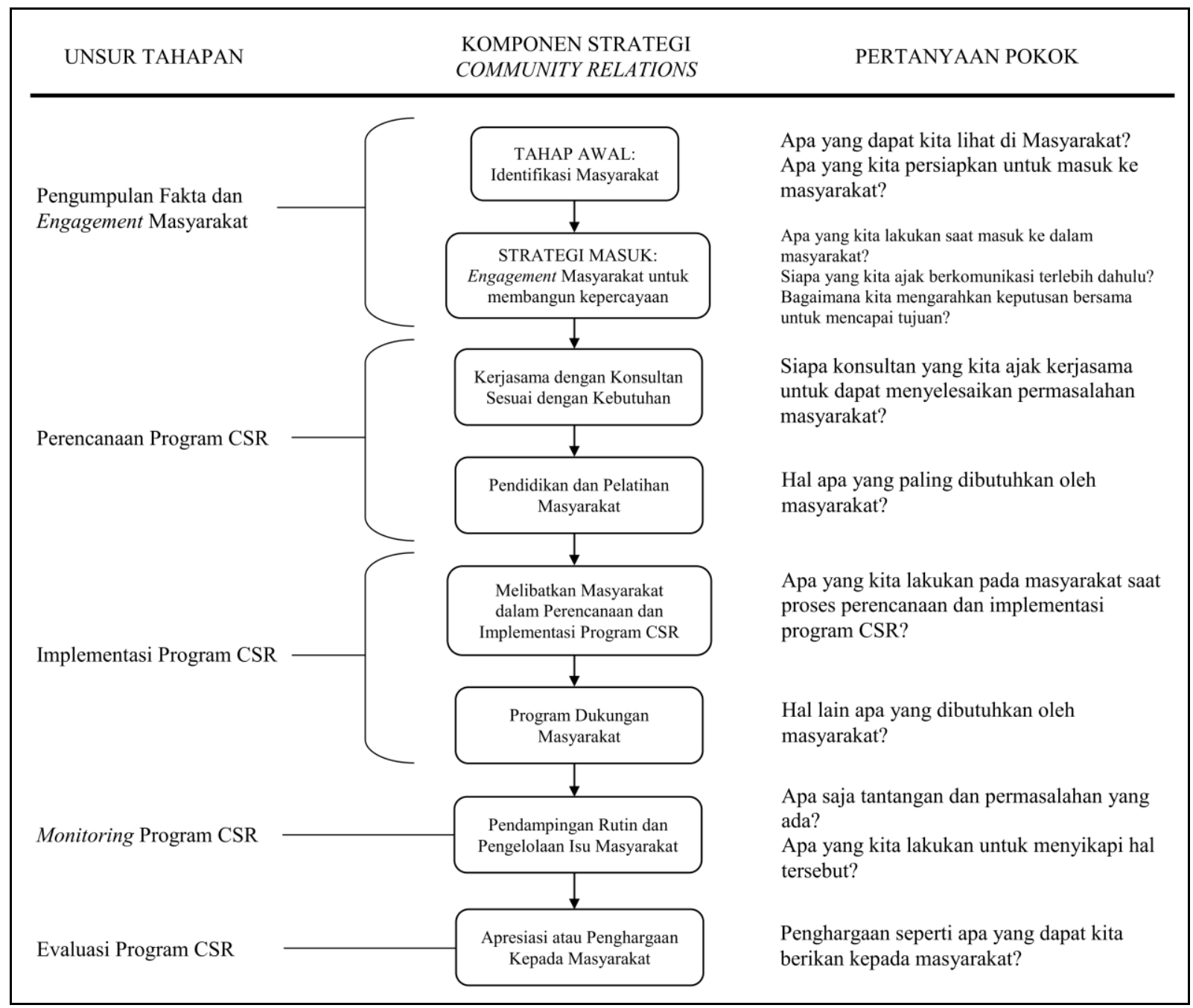

Bagan 1. Analisis \& Intepretasi Strategi Community Relations PHE WMO

identifikasi masyarakat, melakukan engagement masyarakat, melakukan kerjasama dengan konsultan sesuai kebutuhan, memberikan pendidikan dan pelatihan kepada masyarakat, melibatkan masyarakat dalam perencanaan dan implementasi program CSR, melakukan pendampingan rutin dan pengelolaan isu masyarakat, memberikan program dukungan masyarakat, dan memberikan apresiasi atau penghargaan kepada masyarakat.

\section{DAFTAR PUSTAKA}

Ardianto, Dr. E., Machfudz, Drs. Dindin M. (2011). Efek Kedermawanan Pebisnis dan CSR. Jakarta: Elex Media Komputindo.

Burke, E. M. (2001). Corporate Community Relations: The Principle of The Neighbour of Choice. London: Greenwood Publishing Group.

Gregory, A. (2004). Public Relations dalam Praktik. Jakarta: PT. Gelora Aksara.
Grunig, Larissa A., Grunig, James E., Dozier, David M. (2002). Excellent Public Relations and Effective Organization. London: Lawrence Elbaum Associates Publishers.

Harahap, Hikmat. (2007). Strategi Pemberdayaan Masyarakat. Bandung: Humaniora.

Iriantara, Y. (2013). Community Relations: Konsep dan Aplikasinya. Jakarta: Simbiosa Rekatama Media.

Kementrian Lingkungan Hidup dan Kehutanan Indonesia. (2015). Publikasi Pengahargaan Proper. Jakarta: KLHK.

Laporan Berkelanjutan Pertamina Hulu Energi West Madura Offshore. (2015). Sustainability Report 2015: Sinergy and Share. PHE WMO: Jakarta

Moleong, L. J. (2010). Metode Penelitian Kualitatif (Edisi Revisi). Bandung: PT Remaja Rosdakarya.

Wibisono, Y. (2007). Membedah Konsep dan Aplikasi CSR. Gresik: Fascho Publishing. 
Yin, Robert K. (2009). Studi Kasus: Desain dan Metode. Jakarta: PT Raja Grafindo Persada.

AntaraNews.com. (2016). 12 Perusahaan Ramah Lingkungan dapat PROPER Emas 2016. Retrieved 3 Februari from http://www.antaranews.com/berita/ 600326/12-perusahaan-ramahlingkungan-dapat-proper-emas

CNN Indonesia. (2017). Youtube: Raja Minyak Indonesia. Retrieved 3 Februari from https://www. youtube.com/watch?v=_7hzslRNhBQ.

EnergiToday.com. (2013). PHE WMO Tanam 10.000 Bibit Mangrove di Madura. Retrieved 3 Februari from http://www.energitoday.com/ 2013/06/phe-west-madura-offshore-tanam-10000-bibit-mangrove-di-madura/.
JawaPos.com. (2016). PHE WMO Raih PROPER Emas. Retrieved 3 Februari from http://www. jawapos.com/read/2016/12/16/71378/phe-wmoraih-proper-emas.

Metrotvnews.com. (2016). Mei 2016, Produksi Migas PHE WMO Lampaui 100\%. Retrieved 3 Februari from http://ekonomi.metrotvnews.com/ energi/5b2M rjvN-mei-2016-produksi- migasphe-wmo-lampaui-100.

Peraturan.go.id. (2017). Undang-Undang Pemerintah RI No. 27 Tahun 1999. Retrieved 17 Mei from http://peraturan.go.id/uu/nomor-27-tahun-1999. html. 